\title{
電力系統の内部共振回避に関する基礎的検討
}

$\begin{array}{lllll}\text { 正員 } & \text { 餘利野 } & \text { 直 } & \text { (広島大) } \\ \text { 正員 久 保 } & \text { 喜 } & \text { 義 } & \text { (広島 大) } \\ \text { 正員 佐々木 } & \text { 博 } & \text { 司 } & \text { (広島 } 大 \text { ) } \\ \text { 正員 田村 } & \text { 康 } & \text { 男 } & \text { (早稲田大) }\end{array}$

\section{A Basic Study on Avoidance of Auto-Parametric Resonance in Power Systems}

Naoto Yorino, Member, Kiyoshi Kubo, Member, Hiroshi Sasaki, Member (Hiroshima

University), Yasuo Tamura, Member (Waseda University)

Auto-parametric resonance (internal resonance) is regarded as a kind of nonlinear oscillation stemming from the nonlinearity of synchronizing power of generators. The resonance is closely related to power system stability, especially to unstable oscillation phenomena such as "negative damping" and "sustained oscillation". The authors have already developed a quantitative analysis method and proposed a stability index to estimate power system's viability under resonance condition.

This paper studies a countermeasure to prevent auto-parametric resonance, taking two-mode resonance as a representative example of auto-parametric resonance. First, a control index, which is used as the control objective, is established based on the stability index which has been developed in our earlier works. Then, we examine system parameters governing the control index through sensitivity analysis, and propose an effective method of monitoring and control. The proposed control method can be integrated into the conventional ELD by adding another constraint relating to the resonance to conventional security constraints. The effectiveness of the proposed method is demonstrated using a longitudinal 4-machine system through numerical simulations.

\section{キーワード：内部共振，パラメータ共振，非線形振動，弱制動現象，安定度指標，電力系統制御}

\section{1.はじめに}

電力系統におけるパラメータ共振は，系の非線形性 に起因する現象であり，外部形と内部形の二つのタイ プに大別される ${ }^{(1) \sim(6)}$ 。外部形パラメータ共振は，負 荷の周期変動などの系統の外部から加わる周期外乱に 対する発電機動摇を問題とするものである。一方, 内 部形パラメータ共振（内部共振）は，系統過渡動摇時 の振動モード間での共振現象である。本共振は，周期 外乱が存在しない場合にも発生し，また系統状態に依 存して各振動モード間での複雑なエネルギー授受を伴 うため、電力系統安定度を考えるうえで極めて重要と 考えられる。内部共振が発生すると，例えば，外乱発
生後の数秒から数十秒の時間スケールで発電機動摇が 発散と滅衰を絽返すなどの現象が発生し，場合によっ ては外乱発生後数十秒において発電機の脱調を引起こ す可能性もある(1)。このように，内部共振は，負制動 あるいは弱制動現象などと極めて密接なかかわりをも つものと考えられる。

これまで，実振動波形に弱制動現象が観測された場 合，原非線形システムの線形化に基づいた固有值実部 (いわのる制動係数)のみが議諭の対象となり，系を 線形化する際に切搭てられる非線形性の影響が解析さ れることはほとんどなかった。系の非線形性を考虑す る場合, 上記の固有值の実部は, 実現象の制動を単に 近似しているに過ぎず，従って誤差を有する。そし 
てこの非線形性に起因する愦差が小さい場合にのみ 上記の固有值実部は高精度で実現象の制動を知る手段 となる。一方，この嘿差の発散こそが，本論文で扱う 内部共振である。

以上のように, 内部共振は線形化解析の立場から見 れば単に解析不能な誴差の発散として扱われるが、二 次の非線形解析の立場においては，十分に解析可能な 現象である。この場合, 線形化解析における固有値も 取込まれる形で，上り箃密な式により振動現象が記述 される。この点に関して, 著者らは, 内部共振に関し 振動の包絡線（エンベロープ）を変数にもつ非線形微 分方程式（エンベロープ方程式）による解析法を開発 し(2), 更にエンベロープ方程式の解析によって, 内部 共振の振幅 $R A$ (Resonance Amplitude) おるよび共振 の発生する周波数幅 $R W$ (Resonance Width) の理 論式を導出し，それらを指標として提案している(1)。 そして,これらの検証として，3機系の模擬送電線実 験を行い, 従来の（固有値解析と等価な）線形化に基 づく論理式，本理論に基づくより㡿密な式，シミュレ ーション波形，実験波形の 4 者を比較した ${ }^{(3)}$ 。この結 果, 共振条件下において, 線形化解析は, 大きな暻差 を有すること，本理論は良好に機能し得ることなどが 確認されている。このことから, 内部共振は, 過渡安 定度に影響する一大要因と考えられ，著者らは実系統 あるいは過渡安定度シミュレーションにおける弱制動 現象の多くに，本共振が関与していると考えている。 ただし，実系統における検討はこれまで行われておら ずここれは今後の課題である。このように本共振の解 析面に関しては，ある程度の知見を得るに至っている がそその制御に関してはこれまで検討が行われてい ない。

そこで本論文では，内部共振のうち最も代表的な 2 モード間共振を例にとり，その制御法に関する基礎 的な検討を行う。まず，上記の指標 $R W$ を用いて内 部共振を激しくする要因を明確にし，系統の可制御な パラメータとして発電機出力がこれらの要因に与える 影響を検討する。そして，これに基づいて発電機負荷 配分に上る制御手法を提案し, 感度解析, シミュレー ションなどによりこの有効性を示す。本手法は, 経済 負荷配分などとの協調も可能で，また共振条件の下で 従来のPSSなどの制御装置とは全く異なった考え方 て，実際の振動の制動を強化し，安定度を向上させる 手法である。すなわち, 従来の制御装置が振動の線形 部分に相当する制動係数を受けもち, 非線形部分, す なわち内部共振を本手法で制御することで, 結果的に 両者の協調の下に電力系統安定度を向上させる方式で
ある。

\section{2. 内部共振の安定化の可能性}

\section{$\langle 2 \cdot 1\rangle$ 系統の運用状態と内部共振発生の警戒状態}

内部共振は $n$ 機系統において, 系統の固有周波数 $\left(\omega_{i}, i=1, \cdots n-1\right)$ の間に次の関係が成り立つ場合に 発生する ${ }^{(2)}$ 。

$$
\begin{aligned}
& \omega_{q}=2 \omega_{p}+\sigma \quad(2 \text { モード間共振 }) \cdots \cdots \\
& \omega_{q}=\omega_{p}+\omega_{r}+\sigma \quad(3 \text { モード間共振 }) \\
& \text { ただし， } \sigma: \text { 共振のずれ。 }
\end{aligned}
$$

このとき, 内部共振の激しさは系統の運用条件によ って決まり，それは具体的には以下の五つの要因： （イ）共振のずれ $\sigma ，(口)$ 系の制動（慣性モードの制動 保数：固有値実部)，（八)外乱の大きさ（二）重負荷 の程度，(木)共振周波数 $\omega$ によって決まる(1)。

このうち，(イ（口)(二)(ホ)は定常的な系統の運用 状態を表しているのに対して，(八)は，いわば内部共 振の引き金であり，定常状態に扔いて不確定な要因で あると言える。ここで，前者の要因がすべて整い，後 者の要因，つまりある大きさの外乱が系に印加された ならば，共振が直ちに発生し得る状態を，特に「警戒 状態（alert state）」と定義しておく。内部共振の安 定度指標 $R W$ を用いると，この状態は， $\sigma$ が $R W$ の 範囲内に入っている状態，すなわち， $-R W / 2<\sigma<$ $R W / 2$ として判別することが可能である。

本論文では，系統の運用状態を内部共振の立場で監 視し，系統が特に警戒を要する状態にあるならば，運 用状態を内部共振の回避方向に移行させ，系統の安定 化を図る方策を考える。

〈2・2〉 評洒規範の決定 内部共振の立場から系 統の安定化を図るにあたり運用状態の評価規範を決定 しておく。

指標 $R W$ は，前節で述べたように共振の発生する 理論的な $\sigma$ のしきい值を意味しており，。との比較に 際して物理的意味が明確である。この点を考慮し，こ こでは $R W$ と $\sigma$ を用いて, 次のような評価規範 $I$ を 導入する。

$$
I \triangleq R W / 2-|\sigma|
$$


戒状態) 正の值をとる。そして，RWの定義から明 らかなように，その值が大きいほど激しい共振を懸念 しなければならない。一方，この值が負のときには， 理論的に共振が発生し得ない状況を意味している。従 って，系統を監視する際には，このIが正の值をと った場合に共振回避の制御動作を発動し，その制御に 


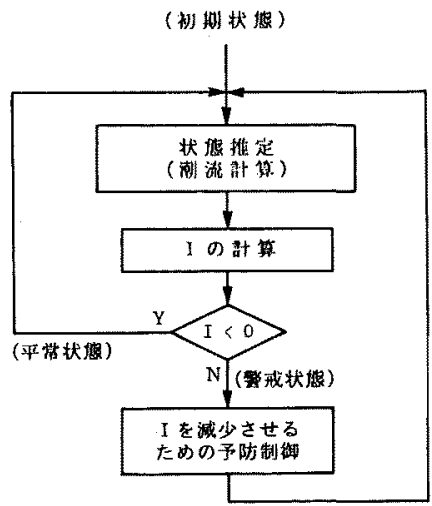

図 1 指標 $I$ に基づく系統監視および 制御法

Fig. 1. Method of monitoring and control based on index $I$.

あたっては、このIを縮小することを制御則とすれ ばよい。そして，適切な制御によってIが急の值に 回復すれば，共振回避の制御動作は終了する。以上の 手続きを図1に示しておく。

ここで，(3)式のIについて若干の補足を行って おく。まえがきで述べたように，著者らは文献 $(2) に$ 扔いて, 従来の線形化理論を更に箃密化した方程式 （エンベロープ方程式）を導出し，非線形振動の発 散・減衰をより正確に知る手段を得た。ここで，従来 の線形化理論による固有振動の方程式はエンベロープ 方程式の近似式に相当し，両者は密接な関係をもつ。 このとき，(3)式の $I<0$ は，両者がほぼ等価な条件 であり，I>0 は両者が等価でないことを意味してい る。すなわち，I>0の場合, 線形化理論の近似は悪 化し，実際の系の振動を知るうえでは，あまり意味を もたなくなる。すなわち，I>0は共振発生の必要十 分条件に相当している。ただし， $I>0$ においても共 振に関与するパラメータの相互作用により，共振が直 ちに振動減衰の悪化に結びつくとは限らないが,ここ では上記 $I$ を制御することで振動減衰の悪化要因を 未然に取除いてしまうことを目的としている。

本論文では，共振回避に関する基礎的な検討が目的 であるので，以下 2 モード間共振のみを対象とし，具 体的な制御方法を検討する。

〈2・3〉 勃率的制御パラメータの理論的考察 こ こでは, 前節の評価規範 $I$ を効率的に制御できる制 御パラメータについて考察する。このとき, 制御パラ メータとして優れるものは, 制御が容易かつこの感度 值が大きいものである。

上述の目的に際し， $R W$ の定義式から再考する。


非線形性まで考慮すると, 第 $i$ 番目の発電機の位相角 $\theta_{i}$ について次式が成り立つ(1)(動摇方程式)。

$$
\begin{aligned}
& \frac{2 H_{i}}{\omega_{R}} \Delta \ddot{\theta}_{i}+\frac{D_{i}}{\omega_{R}} \Delta \dot{\theta}_{i} \\
& =\sum_{j=1}^{n} j_{i j} \Delta \theta_{j}+\sum_{j=1}^{n} \sum_{k=1}^{n} \Delta \theta_{j} b_{k k}^{(i)} \Delta \theta_{k} \\
& \quad(i=1 \cdots n) \quad \cdots \cdots \cdots \cdots \cdots \cdots \cdots \cdots \cdots \cdots
\end{aligned}
$$

ただし， $H_{i}$ : 慣性定数 (s)， $D_{i}$ : 制動係数 $(\mathrm{pu}) ， \omega_{k}$ : 運用周波数 $(\mathrm{rad} / \mathrm{s}), j_{i j}$ : 上式の 平衡点（=運用点 $\theta_{0}$ ) に扔けるヤコビアン 行列の要素 $\left(\boldsymbol{J}=\left[j_{i j}\right]\right), b_{j k}^{(i)}$ : ヘシアン行列の 要素 $\left(\boldsymbol{B}^{(i)} \triangleq\left[b_{j k}^{(i)}\right]\right)$

また，ガバナ，AVRなどの制御系は $D_{i}$ として考 慮している。この場合の $D_{i}$ は, (4)式の固有值の実 部と虚部の比が制御系を含めた詳細システムの慣性モ ードの固有值のそれにできるだけ等しくなるよう, 選

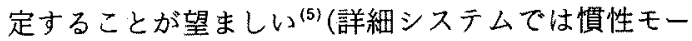
ド以外に様々な固有值が出現するが，これらの共振に ついては今後検討が必要かもしれない）。

ここで，次のマトリックスを定義する。

$$
\begin{aligned}
& \boldsymbol{H} \cong\left[h_{i i}\right]=\operatorname{diag}\left[2 H_{1} / \omega_{1} \cdots 2 H_{n} / \omega_{n}\right] \\
& \boldsymbol{D} \triangleq\left[d_{i i}\right]=\operatorname{diag}\left[D_{1} / \omega_{1} \cdots D_{n} / \omega_{n}\right] \cdots \\
& \boldsymbol{A} \triangleq\left[a_{i j}\right]=-\boldsymbol{H}^{-1} \boldsymbol{J} \cdots \cdots \cdots \cdots \cdots \cdots \cdots
\end{aligned}
$$

$\boldsymbol{A}$ の固有值を $\lambda_{i}(i=1 \cdots n)$, その右固有べクトル を $\boldsymbol{u}^{i}=\left[u_{1}^{i} \cdots u_{n}^{i}\right]^{r}$, 左固有べクトルを $\boldsymbol{v}^{i}=\left[v_{1}^{i} \cdots v_{n}^{i}\right]$ と する。このとき，(1)式の共振に対して $R W$ は次式 で与えられる(1)。

$$
R W \triangleq 2 \sqrt{K^{2}-\mu_{p p}^{2}}
$$
ただし,

$$
\left.\begin{array}{l}
K=\frac{M_{q p}^{(p)}}{\omega_{p}} x_{q 0} \\
\mu_{p p}=\sum_{j=1}^{n} v_{j}^{p} d_{p p} u_{j}^{p}: \text { (口) } \\
x_{q 0}: \text { 仮想外乱 }(30 \mathrm{deg}):(\text { ( ) }
\end{array}\right\} \cdots \cdots
$$

添字は成分，肩字は振動モードの番号を表す。

ここで，(11)式の $\lambda_{p}$ は前述のように(7) 式の行列 $A$ の固有值であり，(4)式のシステム行列の固有值 とは異なる。そして，神は非負の実数となることが 保証されているにここで, システム行列の固有値 $\Lambda_{p}$ （複素数）は上記の $\mu_{p p}, \omega_{p}$ を用いれば $\Lambda_{p} \approx \mu_{p p} / 2$ $\pm j \omega_{p}$ として表される。本論文では， $\Lambda_{p}$ の実部，虚 
部の近似值として， $\mu_{p p}$ と $\omega_{p}$ を用いている】。 以下，上記の各項について述べると，まず $\mu_{p p}$ は系 の制動であり，前述の要因(口)に相当する。また， $x_{90}$ は(八)に相当するもので, 系に加わる外乱を振動 $x_{q}$ の初期変位 $x_{q 0}$ として表したものである。ここで は $x_{q 0}$ として $30 \mathrm{deg}$ を仮定している。 $M_{q p}^{(p)}$ は二次の 非線形性を表す係数で,これは系の負荷状態に依存す るため, 要因(二)に相当する。更に，訨は(木)に相 当する固有周波数である。

以上のような $R W$ の定義式より，規範 $I$ の任意の パラメータ $\beta$ に対する感度は以下のように表される。

$$
\begin{aligned}
\frac{\partial I}{\partial \beta}= & \frac{\partial R W / 2}{\partial \mu_{p p}} \frac{\partial \mu_{p p}}{\partial \beta}+\frac{\partial R W / 2}{\partial M_{q p}^{(p)}} \frac{\partial M_{q p}^{(p)}}{\partial \beta} \\
& +\frac{\partial R W / 2}{\partial \omega_{p}} \frac{\partial \omega_{p}}{\partial \beta}-\frac{\partial|\sigma|}{\partial \beta} \ldots \ldots \ldots \ldots \ldots
\end{aligned}
$$

以下では，上式の各項について考察を加える。ま ず，第 1 項 $\partial \mu_{p p} / \partial \beta$ 注任意パラメータ $\beta$ に関するシ ステムの制動係数の感度を意味しており, 通常これは AVR，ガバナ，PSSといった制御装置のパラメータ に大きく依存している。言い換えれば，従来の系の制 動を強化する系統安定化手法は，パラメー夕共振を回 避する意味でも有効であることが理解できる。従って 本論文では，このような従来の方式と協調する他の方 式を検討する。

第 2 項の $\partial M_{q p}^{(p)} / \partial \beta$ に関して, (10)式の $M_{q p}^{(p)}$ は $A$ の固有べクトルよりなる $v$ および $F$, 発電機の慣性 定数よりなる $h_{i i}$ および(4)式の二次の非線形項 $b_{j j}^{(k)}$ より構成されているが，このうち制御パラメータとし て有効と考えられるものは， $b_{j j}^{(k)}$ のみである。一般 に, 重負荷な運用状態が強い非線形領域での運用を意 味することは広く知られておりこの $b_{j j}^{(k)}$ に関して は負荷状態に大さく依存することが予想される。この ため, 発電機の出力調整によって $b_{j j}^{(k)}$ の制御が可能 と考元られる。第 3 項の固有周波数 $\omega$ に関しても， 一般に負荷状態との関連が強いことが知られている。 また，第 4 項の で第 3 項と同様である。これより，第 2 項から第 4 項 に関して, 発電機の出力調整, すなわち, 負荷配分に よる制御が有効であることが理論的に予測される。

以下では，(12)式の $\beta$ として発電機出力 $P_{i}$ を採用 し，シミュレーションによる検討を加え，これに基づ いた制御方式を提案する。

\section{3. 制御則の決定}

〈3・1〉感度解析によるIの制御効率 まず， (12)式右辺の各項の值をシミュレーションによって数

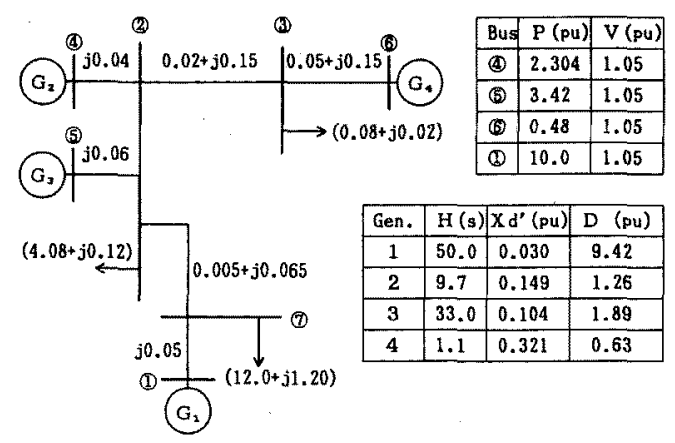

図 2 例題系統扔上び系統パラメー夕

Fig. 2. Example system and system parameters.

值的に検討し, 各項が $I$ の変化に与える寄与の度合 を比較しておく。

（1）シミュレーション方法 モデル系統とし て, 文献 (7)より図 2 に示す系統を引用する。このモ デル系統は，4機系であるから三つの振動モードが存 在する（4番目のモードは振動の中心に相当する零モ ードであり，これは考察外である)。この振動モード の周波数を周波数の低いほうから順に $\omega_{p}, \omega_{q}, \omega_{r}$ と しておく。

$\omega_{p}=4.489, \omega_{q}=8.831, \omega_{r}=15.227(\mathrm{rad} / \mathrm{s})$

ここで、この系統に内部共振を発生させるため，原 文献の 2 番の発電機の慣性定数を変更し, $\omega_{q} \fallingdotseq 2 \omega_{p}$ としている。使用した系統定数は，すべて図 2 に示 した。

シミュレーションでは，まず図 2 の運用状態におい て次式の需給バランス制約：

$$
\sum_{i=1}^{n} \Delta P_{i}=0
$$

を考元，発電機端子電圧を一定として，2台の発電機 に微小な出力変化 $\Delta P_{i}=-\Delta P_{j}=0.01 \mathrm{pu}$ を气る。 そして，そのときの(12)式のパラメータに対して，感 度值を計算するものとした（詳細手順については付録 1 を参照)。表 1 (a)にこの操作による制動係数 $\mu_{i}$, 固有周波数 $\omega_{i}$ おょび $M_{q p}^{(p)}$ の感度値, 同表(b)に， (12)式右辺の各項に相当する感度値を示す。

（2）制御効率の検討 まず，表 1 （a）に注目す ると各発電機 $P_{i}$ に関して, 制動係数 $\mu_{p p}, \mu_{q q}, \mu_{r \tau}$ の 感度は他に比較して極めて低いことがわかる。また， 固有周波数に関しては，全体的に高い感度を示してい るが，概して $\omega_{p}, \omega_{q}, \omega_{+}$の順に大きな值をもち，一 般的な傾向として, 周波数の高いモードほど制御が容 易であることが確認できる。また， $M_{q p}^{(p)} に$ 関しても， 
表 $1 \mu, \omega, M_{p q}^{(p)}$ の感度 $(\partial \alpha / \partial \beta)$ と指標 $I の$ 構成要因の感度

Table 1. Sensitivities of $\mu, \omega, M_{p q}^{(k)}(\partial \alpha / \partial \beta)$, and factors constituting index $I$.

(a) $\mu, \omega, M_{p_{0}}^{(p)}$ 感度 $(\partial \alpha / \partial \beta)$

\begin{tabular}{c|c|c|c|c}
\hline$\alpha$ & $P_{1}$ & $P_{2}$ & $P_{3}$ & $P_{4}$ \\
\hline$\mu_{p p}$ & -0.0091 & 0.0025 & 0.0051 & 0.0015 \\
$\mu_{q q}$ & -0.00015 & -0.00065 & 0.00015 & 0.00065 \\
$\mu_{r r}$ & 0.00055 & 0.00055 & 0.00045 & -0.00155 \\
$\omega_{p}$ & -0.115 & 0.065 & 0.00 & 0.050 \\
$\omega_{q}$ & 0.033 & -0.107 & 0.041 & 0.033 \\
$\omega_{r}$ & 0.153 & 0.153 & 0.153 & -0.458 \\
$M_{q p}^{(p)}$ & 0.177 & -0.347 & 0.308 & -0.138 \\
\hline
\end{tabular}

(b) 指標 $I$ の構成要因の感度

\begin{tabular}{c|c|c|c|c}
\hline$i$ & 1 & 2 & 3 & 4 \\
\hline$\frac{\partial R W / 2}{\partial \mu_{p \phi}} \frac{\partial \mu_{p p}}{\partial P i}$ & 0.0016 & -0.0043 & -0.00087 & -0.00026 \\
\hline$\frac{\partial R W / 2}{\partial \omega_{p}} \frac{\partial \omega_{\rho}}{\partial P_{i}}$ & 0.0161 & -0.0091 & 0.00 & -0.0070 \\
\hline$\frac{\partial R W / 2}{\partial M_{\varphi \rho}} \frac{\partial M_{q p}^{(\phi)}}{\partial P_{i}}$ & 0.0414 & -0.0812 & 0.0721 & -0.0323 \\
\hline$\frac{\partial \sigma}{\partial P_{i}}$ & 0.262 & -0.236 & 0.040 & -0.066 \\
\hline
\end{tabular}

$\omega$ と同様に值が大きく, 可制御なパラメータであるこ とがわかる。

以上の結果は, 表 1 (b)に極めて明確に反映されて いる。すなわち，(12)式の第 1 項に相当する同表の第 1 行目の值 $0.0016,-0.0043$ などは, 他に比較して 非常に小さい値であり，こ机は制動係数の感度に起因 するものであることが理解できる。また，その他の行 に関しては，第 2，3，4 行の順に值が大きくなってお り,これより(12)式の各項に扔いて, 最終項に相当す る $\sigma$ を制御するのが，最も効果的であることが判断 できる。

以上の検討を基に，(12）の感度計算において正確さ と計算量の関連から，どの項までを考慮するかを決定 すればよいことになる。すなわち，正確さを追求する 場合は全項を，また計算量を節約する場合は第 4 項も しくは第 3 項以降を用いることになる。

ここでは，ほほ完全に無視し得ると思われる(12)式 の右辺第 1 項を除いた次式を用いることにする。

$$
\begin{aligned}
\frac{\partial I}{\partial P_{i}}= & \frac{1}{2} \frac{\partial R W}{\partial M_{q p}^{(p)}} \frac{\partial M_{q p}^{(p)}}{\partial P_{i}} \\
& +\frac{1}{2} \frac{\partial R W}{\partial \omega_{p}} \frac{\partial \omega_{p}}{\partial P_{i}}-\frac{\partial|\sigma|}{\partial P_{i}}
\end{aligned}
$$

〈3・2〉 感度計算の理論式 ここでは, 前節で行 ったシミュレーションによる感度計算に比較して, 実
表 2 感度係数の比較

Table 2. Sensitivity coefficients.

\begin{tabular}{c|c|c|c|c}
\hline$i$ & 1 & \multicolumn{1}{|c|}{2} & 3 & 4 \\
\hline$\frac{\partial R W / 2}{\partial \omega_{p}} \frac{\partial \omega_{p}}{\partial P_{i}}$ & 0.0161 & -0.0091 & 0.00 & -0.0070 \\
\hline$\frac{\partial R W / 2}{\partial M_{q p}^{(p)}} \frac{\partial M_{q p}^{(p)}}{\partial P_{i}}$ & 0.0086 & -0.0057 & 0.0028 & -0.0057 \\
\hline$\frac{\partial \sigma}{\partial P_{i}}$ & 0.0870 & -0.0812 & 0.0721 & -0.0323 \\
\hline$\frac{\partial I}{\partial P_{i}}$ & 0.262 & -0.236 & 0.040 & -0.066 \\
\hline
\end{tabular}

上段：シミュレーション傍，下段：理論値

際上，計算効率が良いと考えられる感度の理論式を導 出し，系統制御に使用する際の検討を行う。

（1）感度の理論式 以下に，(14)式の各項につ いて定義に従って(8)〜(11)式を微分し, その結果求 められた理論式を示す。

$$
\begin{aligned}
& \frac{\partial R W / 2}{\partial M_{q p}^{(p)}}=\frac{\left(X_{q 0} / \omega_{p}\right)^{2} M_{q p}^{(p)}}{2 R W} \\
& \frac{\partial M_{q p}^{(p)}}{\partial P_{i}}=\frac{1}{2} \sum_{k=1}^{n} \frac{v_{k}^{p}}{h_{k k}} \sum_{j=1 \neq k}^{n} F_{k j}^{q p} j_{k j} \\
& \times\left(j_{j i}^{-1}-j_{h i}^{-1}\right) \\
& \frac{\partial R W / 2}{\partial \omega_{p}}=-\frac{\left(M_{q p}^{(p)} X_{q 0}\right)^{2} \omega_{p}^{-3}}{2 R W} \\
& \frac{\partial \omega_{p}}{\partial P_{i}}=\frac{1}{2 \omega_{p}} \sum_{k=1}^{n} \frac{v_{k}^{p}}{h_{k k}} \sum_{j=1 \neq k}^{n}\left(u_{k}^{p}-u_{j}^{p}\right) \\
& \times\left(j_{k i}^{-1}-j_{j i}^{-1}\right) b_{j j}^{\langle k\rangle} \\
& \frac{\partial|\sigma|}{\partial P_{i}}=\operatorname{sign}(\sigma)\left\{\frac{\partial \omega_{q}}{\partial P_{i}}-2 \frac{\partial \omega_{p}}{\partial P_{i}}\right\}
\end{aligned}
$$

ただし，

$$
\operatorname{sign}(\sigma)= \begin{cases}-1 & (\sigma<0) \\ +1 & (\sigma \geqq 0)\end{cases}
$$

ここで，(15)〜 (20) 式の導出に際しては, 前節のシ ミュレーションの際考慮した「発電機端子電圧一定」 の条件を考慮していない。また(16)式については，P に対する固有べクトルの変化を無視した。なお，若干 導出が複雑になる $(16),(18)$ 式に関しては, その手順 を付録 2 に示した。

ここで, 上で導出した理論式を検証する意味で, 先 のシミュレーション値と, 理論式より得られた值を比 較しておく。これは，導出の際に用いた仮定の妥当性 を検証する意味で重要である。

表 2 に理論值とシミュレーション值の比較を示す。 モデル系統はかなりの重潮流であり，前述の「発電機 端子電圧一定」の条件が満たされにくいと考えられる が，全体的に表中下段の理論值は，上段のシミュレー 
ション值と近い值をとっており, 導出の際の仮定の妥 当性を裏づけている。また, 結果として得られる $\partial I / \partial P_{i}$ の理論值も, シミュレーション值と十分な精度 で一致していると言える。

図 3 に計算の流れ図を示す。通常 $I$ を計算する場 合, まず潮流解析を行い, 潮流方程式からヤコビアン $\boldsymbol{J}$ 抢よびヘシアン $\boldsymbol{B}$ を得る。次に， $\boldsymbol{J}$ と発電機パラ メータ $\boldsymbol{H}$ より $\boldsymbol{A}$ の固有值解析を行い, 固有值 $\lambda_{i}$ $\left(=\omega_{i}^{2}\right)$ および固有べクトル $\boldsymbol{u}^{i}, \boldsymbol{v}^{i}(i=1 \cdots n)$ を得 る。そして,これらの值より共振モードの $\sigma$ と $W$ の計算を行い，Iが計算される。このような流れに対 して(14)式は, 潮流解析におけるJの逆行列 $\boldsymbol{J}^{-1}$ と 固有值解析における固有值, 固有べクトルおよび $R W$ の計算値のみを参照しながら計算される。すな わち, (14)式の計算には, 通常の $I$ の計算で行われ る潮流解析および固有値解析以外に, 特別な手続きを 必要としない。従って, $I$ の計算の後, あるいは $I$ の 計算と並行して，極めて効率的に(14)式を計算するこ とが可能である。

〈3・3〉制御法について 次に, 具体的な制御法 について述べる。各発電機の出力を変化させたときの $I$ の変化は，(14)式を用いて, 次式で定量的に評価で きる。

$$
\Delta I=\sum_{i=1}^{n} \frac{\partial I}{\partial P_{i}} \Delta P_{i}
$$

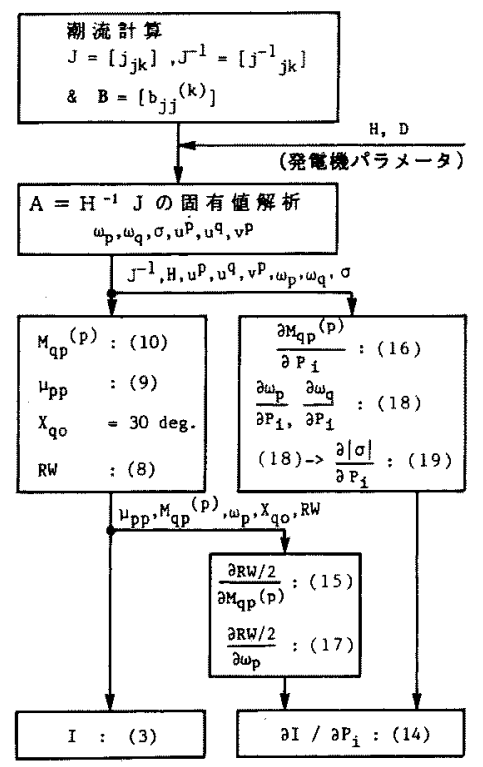

図 3 指標 $I$ とその感度の詳細計算手順 Fig. 3. Detailed procedure for computing index $I$ and its sensitivities.
従って, 図 1 の系統監視によって, 常時 $I$ の値が 監視されてい机ば，運用者はその時点で予定される制 御 $\Delta P_{i}$ に対して(21)式の $\Delta I$ を計算し, 制御後の $I$ の 值を知ることができる。ここで重要な点は，(13)式の 制約の下で， $\Delta I$ が急になるような $\Delta P_{i}$ は一意ではな く,このためIの值を小さくする負荷配分の方法に は非常に柔軟性があることである。従って，(21)式と 現在の $I$ の值 $I_{0}$ を用いて,

$$
I_{0}+\sum_{i=1}^{n}\left(\frac{\partial I}{\partial P_{i}}\right) \Delta P_{i}<0
$$

を線路過負荷などの一連の制約条件に加えれば，本方 式は従来の経済負荷配分に組合せて用いることも可能 である。このように, 本方式では経昘性, 信頼性など に基づく既存の様々な制御方式との協調が可能である と考えられる。なお，前述のように，本制御は基本的 に定態安定度, 過渡安定度などの安定度向上策の一種 であり，従来の AVR，ガバナ，PSS といった制御と も本質的に協調する方式である。

\section{4. 制御効果の検証}

ここでは，前節の制御則に基づき図 2 の系統におい て実際に制御を行い，その制御効果を検証する。同図 に示した運用状態をケース 1 とし，その状態から発電 機出力制御 $\Delta P_{i}$ を行った場合を想定し, 表 3 のよう に4ケースを設定した。各ケースの運用状態におい て，図 3 に基づいて計算した $I$ おび $\partial I / \partial P_{i}$ の值を 表 4 に示す。

〈4・1〉指標值の検討 ケース 1 の $I$ の値は 0.160 と正の值であり(表 4), 制御前の運用状態は 「警戒状態」である。制御方法としては,この状態に

表 3 シミュレーションケース

Table 3. Simulation cases.

\begin{tabular}{c|c|c|c|c}
\hline & $\Delta P_{1}$ & $\Delta P_{z}$ & $\Delta P_{3}$ & $\Delta P_{4}$ \\
\hline ケース 1 & 0 & 0 & 0 & 0 \\
\hline ケース 2 & -0.4 & +0.4 & 0 & 0 \\
\hline ケース 3 & 0 & +0.4 & -0.4 & 0 \\
\hline ケース 4 & +0.4 & 0 & -0.4 & 0 \\
\hline
\end{tabular}

表 4 制御前後の指標 $I$ の值

Table 4. Index $I$ before and after control.

\begin{tabular}{c|c|c|c|c|c}
\hline & $I$ & $\frac{\partial I}{\partial P_{1}}$ & $\frac{\partial I}{\partial P_{2}}$ & $\frac{\partial I}{\partial P_{3}}$ & $\frac{\partial I}{\partial P_{4}}$ \\
\hline ケース 1 & 0.160 & 0.249 & -0.236 & 0.076 & -0.089 \\
\hline ケース 2 & -0.006 & 0.223 & -0.249 & 0.103 & -0.077 \\
\hline ケース 3 & 0.012 & 0.277 & -0.262 & 0.074 & -0.088 \\
\hline ケース 4 & 0.274 & 0.316 & -0.254 & 0.042 & -0.105 \\
\hline
\end{tabular}


おける $I$ の感度 $\partial I / \partial P_{i} に お い て ，$ 正の值を有する発 電機出力を低下させ, 負の値のそれを上昇させればよ く，Iの值を改善する負荷配分には柔軟性がある。こ のなかで最も効率的な制御を行うためには, 表 4 より 発電機 1 と 2 の間で出力再配分を行えばよいことがわ かるのでこれをケース 2 とした。同ケースにおい て，表 4 のケースの数值 0.249 とー0.236よりその制 御量を, $\Delta P_{i}=+0.33$ 程度にすれば, 評価規範 $I$ の値 を負にすることができると予想できる。従って，ここ

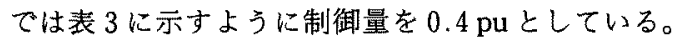
そしてこの結果, 制御後の $I$ は -0.006 となり, 警戒 状態から複帰している。ケース 3 は表 3 に示すよう に,ケース 1 の状態に対し $P_{1}$ の代わりに制御効果の 悪い $P_{3}$ を制御したものである。この結果，Iの值は 大幅な改善が見られるものの0.012 と正の值にとどま つている。なお，この值は，Iの感度に基づいて更に 若干の制御を行えば改善が可能である。ケース4は $P_{1}$ および $P_{3}$ に対して逆制御を行った例である。この 結果，Iの值は 0.274 と更に増大している。

なお，表 4 において，各ケースの感度 $\partial I / \partial P_{i}$ は制 御前後で大きな変化はなく,これは実際の運用におい ても頻繁な感度值の再計算を必要としないことを示唆 している。ただし，この一般性を確認するためには， より現実に近い系統での検討が必要であると考えら れる。

〈4-2〉 $3-L-G$ 後の系統動摇の検討 前節の各 ケースの運用状態に招いて，ここでは，4番母線に 0.02 秒間の $3-L-G$ 故障を発生させ, 故障後の系統動 摇を検討する。発電機として過渡リアクタンス $X_{d}^{\prime}$ 背

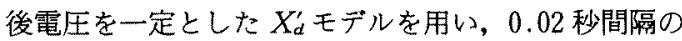
ルンダクッタ法により発電機動摇を求めることでシミ ュレーションを行った。求められた動摇波形の各振動 成分を明確にするために，波形をモード領域 $p, q, r$ に変換し(2)，図4に示すような各モードのエンべロー プ（包絡線） $E M_{i}$ を検討する。図 5 に各ケースの $E M_{i}$ を示す。

まず，制御前のケース1では，（1)式によるモード $q, p$ 間の共振に起因して, 外乱発生後 40 秒程度はモ 一ドかのエンベローブが増大して扔り，振動が発散 的になっている。このように，Iか゚正の值である制御 前のモデル系統は, 内部共振の発生によって見掛け上 の制動が低下している様子がわかる。

これに対し，制御によりIが負となったケース 2 においては，すべてのエンベロープが単調減少してお り，振動の発散傾向が見られない。すなわち，ケース 2 は内部共振を回避したことにより，実際上，負制動

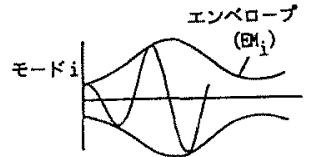

図 4 モード領域における振動の エンベロープ

Fig. 4. Envelope of oscillation in mode space.
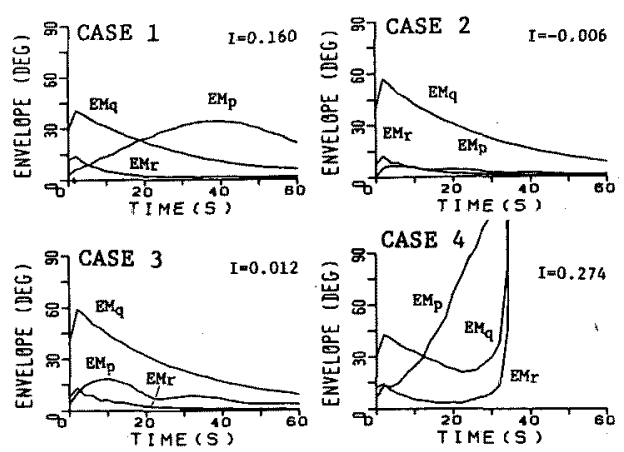

図 5 各ケースに抬ける振動のエンベロープ

Fig. 5. Envelopes of oscillations for each case.

な状態をまぬがれ，系の安定度が向上していると判断 できる。また，Iが微小ながら正の值をとるケース 3 では，EMpにわずかながら発散的傾向が見られ，I の値をよく反映した系統動摇となっている。

一方, 逆制御を行ったケース 4 においては発散傾向 が強められ, 外乱発生後約 30 秒程度で，発電機が脱 調に至っている。

以上より，Iの值は共振の程度をよく反映し,また 提案した制御の有効性を確認することができる。近年 の大規模電力系統に内在する固有周波数は極めて多 く,このため通常の運用状態においても共振条件が成 立する機会はまれではないと考えられる。この点を考 慮すれば，提案法㹥固有值実部を強化する従来の PSS などとは全く異なった考えで，等価的に系の制 動を強化し, 安定度を向上させる方式であると言 える。

\section{5. 終りに}

本論文では, 内部パラメー夕共振の立場から系統の 安定度の向上を図る制御方式について，基礎的検討を 行った。 
まず，系統の状態を評価する規範を設定し，この値 を効率的に制御することのできるパラメータは，発電 機の出力電力であることを示した。

次に, 評価規範 $I$ の各発電機出力変化に対する感 度を理論的に導出し，その有効性を確認した。そし てこれに基づいた系統安定化法を提案し，シミュレ ーションによってその有効性を確認した。

最後に本研究を進めるにあたり，文部省科学研究費 の補助を得たことを付記する。

(平成元年 4 月 21 日受付)

\section{文献}

（1）餘利野·久保・传及木・田村：「電力系統に㧍ける内部形パラ $x$-夕共振指標の提案), 電学論 $\mathrm{B}, 109,387$ (平元-9)

（2）餘利野・田村・佐々木：電力系統に扔ける内部形パラメー夕 共振とその解析手法について」, 同上B，108，321（昭637)

（3）佐竹・餘利野・田村：(電力采統におけるパラメー夕共振の寒 験的確認」，同上 B, 108，81 (昭 63-3)

(4) 餘利野・田村：[䉓力系統におけるバラメー夕共振の分類と特 微抽出」，同上 B，106，503 (昭61-6)

（5）餘利野・與島・久保田・森・田村：「電力系統におけるバラメ 一夕共振について子, 同上 B, 105，805（昭 60-10）

（6）飪利野・森・田村：「電力系統安定度とパラメー夕共振の関係 について」, 同上 $\mathrm{B}, 105,15$ (昭 60-1)

（7） 植田・上之葓：電中研報告, No.72046，18：42（昭 47）

(8) D. K. Faddeev \& V.N. Faddeeva : Computational Methods of Linear Algebla, 228 (1963) Freeman

\section{付 録}

\section{1. 表 1(a) 数值の算出}

表 1 (a)の $\mu, \omega, M$ を記号 $\alpha$ で表すものとすると， まず次式が成り立つ。

$$
\begin{aligned}
& \Delta \alpha=\sum_{i=1}^{n} \frac{\partial \alpha}{\partial P_{i}} \Delta P_{i} \\
& \sum_{i=1}^{n} \frac{\partial \alpha}{\partial P_{i}}=0 \cdots \cdots . . .
\end{aligned}
$$

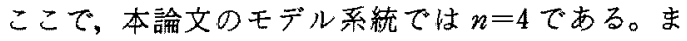
た，(付 2 )式は，(付 3 ) （付 6 )式より得られる。い ま, 図 2 の運用状態から, $\Delta P_{i}=-\Delta P_{j}=0.01 \mathrm{pu}$ の発 電機出力の微小変化を $(i, j)$ と書く。表 $1(\mathrm{a})$ は, ま ずシミュレーションにより $(2,1) ，(3,1) ，(4,1)$ に 対して $\Delta \alpha$ を求め, これら三つの值より，(付 1), (付 2 )式を $\partial \alpha / \partial P_{i}$ について解いた値である。

(付 2 )式の導出は以下のとおりである。まず，(付 2 )式左辺を以下のように表す。

$$
\begin{aligned}
& \sum_{i=1}^{n} \frac{\partial \alpha}{\partial P_{i}}=\sum_{i=1}^{n-1} \frac{\partial \alpha}{\partial P_{i}}+\frac{\partial \alpha}{\partial P_{n}} \\
& \frac{\partial \alpha}{\partial P_{n}}=\sum_{i=1}^{n-1} \frac{\partial \alpha}{\partial P_{i}} \frac{\partial P_{i}}{\partial P_{n}} \cdots \cdots
\end{aligned}
$$

ここで, $\Sigma_{i} P_{i}=$ const. を $P_{j}$ について微分することに より次式を得る。

$$
\frac{\partial P_{i}}{\partial P_{j}}=-1 \quad(i \neq j)
$$

（付 5 )式を(付 4 ) 式に代入すると次式を得る。

$$
\frac{\partial \alpha}{\partial P_{n}}=-\sum_{i=1}^{n-1} \frac{\partial \alpha}{\partial P_{i}}
$$

（付 6 )式を(付 3 ) 式に代入することにより（付 2 )式を 得る。

\section{2. 各微係数の導出}

（1） $\partial M_{q p}^{(p)} / \partial P_{i} \quad P_{i}$ が微小変化するとき，固有 ベクトルの変化は無視し得ると仮定し，（10)式を $P_{i}$ について微分すると次式が得られる。

$$
\begin{aligned}
& \partial M_{q p}^{(p)} / \partial P_{i} \\
& \quad=\sum_{k=1}^{n} \frac{v_{k}^{p}}{h_{k k}} \sum_{j=1 \neq k}^{n} F_{k j}^{q p} \sum_{m=1}^{n} \frac{\partial b_{j j}^{(k)}}{\partial \theta_{m}} \frac{\partial \theta_{m}}{\partial P_{i}}
\end{aligned}
$$

ここで, $\partial \theta_{m} / \partial P_{i}$ は, (4) 式のヤコビアン $\boldsymbol{J}$ の逆行列 の要素として得られる。

$$
\partial \boldsymbol{\theta} / \partial \boldsymbol{P}=\boldsymbol{J}^{-1} \triangleq\left[j_{m i}^{-1}\right]
$$

また, $\partial b_{j j}^{(k)} / \partial \theta_{m}$ とヤコビアンJの要素 $j_{k j}$ の間には 次の関係がある。

$$
\frac{\partial b_{j j}^{(k)}}{\partial \theta_{m}}= \begin{cases}-1 / 2 j_{k j} & (m=k \neq j) \\ 1 / 2 j_{k j} & (m=j \neq k) \\ 0 & (m \neq k, m \neq j)\end{cases}
$$

これらの関係を(付 7 )式に代入すると(16)式を 得る。

(2) $\partial \omega_{p} / \partial P_{i}$ 行列 $A$ の固有值 $\lambda_{i}$ の $P_{i}$ に対す る感度は次式で与えられる ${ }^{(8)}$ 。

$$
\frac{\partial \lambda_{i}}{\partial P_{i}}=v^{i} \frac{\partial A}{\partial P_{i}} u^{i} / v^{i} u^{i}
$$

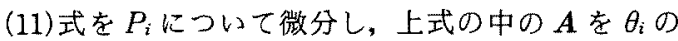
みの関数と考えると次式を得る。

$$
\frac{\partial \omega_{p}}{\partial P_{i}}=\frac{1}{2 \omega_{p}} \boldsymbol{v}^{p} \sum_{m=1}^{n} \frac{\partial \boldsymbol{A}}{\partial \theta_{m}} \frac{\partial \theta_{m}}{\partial P_{i}} \boldsymbol{u}^{p}
$$

ただし， $\boldsymbol{v}_{i} \boldsymbol{u}_{i}=1$ と正規化されているものとする。更 に以下の関係：

$$
\left.\left.\begin{array}{c}
\partial \boldsymbol{A} / \partial \theta_{m}=\left[b_{m g}^{(k)} / h_{k k}\right] \\
\partial \theta_{m} / \partial P_{i}=\left[j_{m i}^{-1}\right] \\
b_{k j}^{(k)}=b_{j k}^{(k)}=-b_{j j}^{(k)} \\
b_{k h}^{(k)}=\sum_{j=1 \neq k}^{n} b_{j j}^{(k)} \\
b_{i j}^{(k)}=0 \quad(i \neq k, j \neq k)
\end{array}\right\} \ldots \ldots \ldots \ldots \ldots \text { (付 } 11\right)
$$




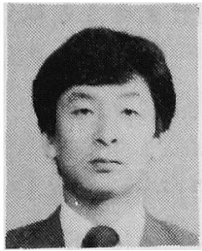

餘利野 直 人（正員）

昭和 33 年 1 月 24 日生。 58 年 3 月早稲田大学大学院修士課程修了。 同年 4 月富士電機製造(株) 入社。59 年 4 月早稲田大学大学院理工学研究 科博士課程に進学。6 60 年 4 月同大学理工学部助手, 62 年 4 月広島大学工学部助手。工学博士。電力系統 安定度および電力系統の経済運用に関する研究に従 事。1985 年 George Montefiore 受賞。IEEE 会員。

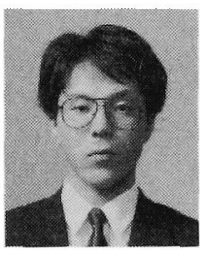

現在に至る。

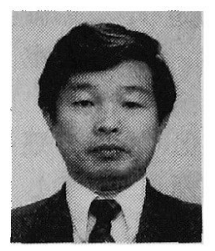

佐々木 博司（正員）

昭和 16 年 3 月 10 日生。 43 年 3 月早稲田大学大学院理工学研究科博 士課程(電気工学専攻) 修了。同年 4 月広島大学工学部電気工学科講師, 55 年 10 月第二類（電気系）助教授，平成元年 11 月 同教授 (電力工学教育科目担当), 現在に至る。主と して, 電力系統の過渡安定度, 状態推定, 最適潮流計 算法, エキスパートシステムの応用に関する研究に従 事。工学博士。IEEE, CIGRE, 日本太陽エネルギー 学会, 情報処理学会, エネルギー・資源研究会会員。

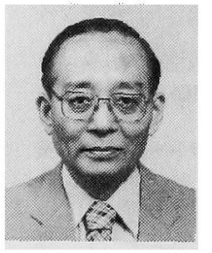

\section{田村 康 男 (正員)}

昭和 6 年 9 月 21 日。 30 年 3 月早 稲田大学大学院修士課程修了。同年 4 月同大学理工学部助手, 44 年 4 月 同教授。工学博士。 45 年, 48 年電 気学会論文賞, 53 年 11 月石川賞, 1985 George Montefiore, 61 年 5 月電気学会電力賞受賞。計測制 御学会, 情報処理学会, シミュレーション技術会, IEEE，CIGRE 会員。 